\title{
FINANCIAL BENCHMARKING THE EXAMPLE OF CONFECTIONERY INDUSTRY COMPANIES
}

\author{
Marina Vasilic ${ }^{1}$
}

\section{Summary}

Being a managerial tool of proven efficiency when it comes to managing companies in crisis periods, benchmarking concept is still insufficiently known and applied in the Republic of Serbia. The idea of this paper was to reveal its possibilities through the aspect of financial benchmarking, showing its simplicity and benefits even from the point of an external analyst. This was achieved through the analysis of two biggest competitors on the market of confectionery products of the Republic of Serbia, using secondary data analysis. Through multidimensional set of performance measures based on profit as the ultimate goal, but also including value for shareholders, liquidity and capitalization, we have confirmed the leader's market position and found its sources, which are the key learning points for the follower to adopt in order to improve its performance.

Key words: benchmarking, performance analysis, confectionery industry, continuous learning.

JEL: M40, M21, G30, Q19

\section{Introduction}

With the development of modern business practice in the Republic of Serbia, the term „,benchmarking“ timidly appeared as a foreign word with an attractive sound, but mostly unknown meaning. Managers who heard about it often misbelieve that benchmarking comes down to the process of measurement of company's performance and its comparison to given standards. Having in mind that experience of developed economies testifies on exceptional significance of benchmarking in managing companies and performance improvement, insufficient knowledge on this managerial instrument and the lack of its use by the managers in the national economy can be considered intolerable, at least.

According to the definition of the American Productivity \& Quality Center (APQC, 1993), the idea of benchmarking lies in systematic and continuous measurement of business processes of an entity, in relation to the business processes of known market leaders anywhere in the world, in order to obtain information which would help the entity to improve its perfor-

1 Marina Vasilić, M.Sc., Teaching Assistant, University of Belgrade, Faculty of Agriculture, Nemanjina Street no. 6, 11080 Zemun, Serbia, Phone: +381 11261 26 64, E-mail: marina.vasilic@agrif.bg.ac.rs 
mance. Essentially, the benchmarking comes down to a simple idea of learning from the best, which proved to be a very efficient instrument for surviving the crisis periods worldwide.

Financial benchmarking is especially attractive and probably one of the most commonly used benchmarking concepts. This is primarily due to the attractiveness of the financial-accounting performance measures. Additional convenience comes from the fact that the whole process can be carried out without the actual knowledge and permission of the benchmarking partner, since most of the information necessary for the analysis is publicly available, due to the requirements of financial reporting regulatory framework. Thereby, companies are given the possibility to benchmark with virtually anyone in the world, in a relatively simple manner and without significant investment.

However, for the benchmarking process to result in information which is even remotely useful for improving company's performance, the selection of benchmarking partner needs to be planned carefully. In other words, if the peaks where best practices operate are so high that they cannot even be seen from the company's perspective, it would probably be more useful to benchmark with some closer leader. Another issue is the selection of the performance indicators. Generally, designing a balanced system of indicators is a challenge which must be overcome in order to create an adequate foundation for making relevant and correct conclusions. This represents the initial premise for performance improvement in the benchmarking process.

The choice of performance indicators is just the initial step. Adequately set, performance indicators provide very useful indices about which moves to play in order to promote company's results and catch up with benchmarking partner. Therefore, the task of performance indicators is not just to position the company against best practices, but to indicate the moves a company can make in order to reach (and outrun) the leader's performance level (or the benchmarking partner's). In this sense, the use of summary performance indicators, although inevitable for investors when evaluating the attractiveness of a potential investment, is considered to be insufficiently useful for financial benchmarking. Summary indicators do not provide information on value drivers, which are the building elements of performances. Performance gap analysis between the benchmarked company and best practice receives its full meaning on the level of value drivers, because of the highest learning potential which exists on this level. If a company manages to move the value drivers in the wanted direction, targeted performance improvement will not betray.

\section{Paper goals}

The subject of this paper is the process of financial benchmarking based on secondary data analysis, presented on the example of two companies from the confectionery industry, operating on the market of the Republic of Serbia. The paper aims to point out the possibilities of using the benchmarking technique in the process of improving company's results and performance, through the analysis of the achievements of a more successful competitor i.e. "best practice", identification of the sources of its performance and the application of the acquired knowledge in strategic and operational decision-making. Our idea was to show 
that even the simplest type of benchmarking, performed using publicly available data, can be a useful source of information and knowledge in managing company's performance, and to indicate the possibility of using more complex benchmarking techniques which require a closer relationship and knowledge sharing between companies in the benchmarking process. Additionally, we wanted to point out that benchmarking analysis is not strictly a tool of business and finance, and that it can and should be used in a wide range of companies, including the agricultural sector. Furthermore, we wanted to examine the cost-effectiveness of this type of benchmarking.

The selection of the benchmarked companies Bambi and Stark enables the financial benchmarking to be carried out between two companies which are the biggest competitors in the market of biscuits and confectionery products in the Republic of Serbia, and at the same time the biggest leaders on this market, therefore the closest leaders (Jašarević, Ličina, 2013). Considering their financial results in the period 2010-2012, we wanted to show how Stark can learn and improve its performance in the near future, benchmarking with Bambi as the "best practice".

\section{Methodology and data sources}

We have tested the following hypotheses in this paper: (1) the methodology of the financial benchmarking is applicable in different types of organizations; (2) the methodology of financial benchmarking is useful for performance improvement; (3) financial benchmarking based on the publicly available data is cost-effective tool.

The research was performed using the secondary data analysis. The set of financial statements of analyzed companies, accompanied by the independent auditor's opinion, both published by the Republic of Serbia Business Registers Agency, was used as the primary data source. Necessary financial market information was collected from the data published by the Belgrade Stock Exchange and Central Securities Depository and Clearing House. Additional information on the operations of the subject companies in the relevant threeyear period and following years were collected from the company websites and other publicly available sources.

Having in mind that both companies have the same reporting framework, consisted of IFRS, IAS and national regulations of the Republic of Serbia, we can expect a relatively high degree of comparability of data published in their financial statements. Harmonization and standardization of the financial statements should result in information which is relevant, credible and comparable (Škarić, 2012). This is one of the important assumptions for the quality of this type of financial benchmarking process. Namely, the identical financial reporting framework and the identical form of financial statements pretend to ensure the comparability of financial information presented by different companies, in form and essence. Publicly available audit reports of the analyzed companies represent an additional guarantee of the quality of their financial statements, having in mind that the auditor's opinion on financial statements of both companies was unqualified for all three years. 
However, it is a fact that an external analyst can never be completely assured in the level of comparability of the official financial statements i.e. the conclusions of his analysis. Without aspirations to analyze the causes of inadequate financial reporting and the possibilities for their overcoming, we draw attention to several important matters - the use of different accounting policies, the risk of numerical and essential errors and misstatements which can remain in the financial statements of a company even after the audit, and the fact that unqualified auditor's opinion is finally just an expert's opinion which cannot represent a complete guarantee of the quality of the financial statements. In addition, the analysis had shown an extraordinary event Stark was involved in - a status change, which significantly affected its annual financial statements for 2012. These restrictions must be taken into notice when interpreting the results of the benchmark analysis. Therefore the results should be taken with commensurate caution.

In the process of financial benchmarking of Bambi and Stark, we used the methodology elaborated on the financial benchmarking course of the $\mathrm{PhD}$ study program of the Faculty of Economics, University of Belgrade. In this respect, multidimensional set of performance measures calculated using the data provided by the secondary analysis was used. Performance indicators were chosen based on their relation to strategic goals of a company. Except for yield as the ultimate strategic goal, companies will often have a whole variety of goals, such as profitability, long-term stability, capitalization, liquidity, growth and dividends (Malinić, 2010). For each of these targets, there are series of indicators which can be used for their quantification. When it comes to choosing the indicators which will be used for benchmarking, it is important to be guided by the principles of cost-effectiveness and sustainability and to choose a relatively small number of wellknown and widely used indicators. It is usually recommended to use ten to fifteen indicators (Malinić, 2010). For the purpose of the analysis, indicators were chosen on the basis of profitability as the ultimate strategic goal, but other goals were included in the analysis as well, such as value for shareholders, liquidity and capitalization, in order to obtain the overview of performance from several different aspects and create a basis for conclusions on possibilities for their promotion.

\section{Results and discussion}

Profitability was analyzed using Return on common equity (Table 1). This indicator is especially useful because it can be broken down to its structural parts, which enables performance analysis on the level of value drivers (Malinić, 2010).

Comparing ROCE (Picture 1) it is obvious Bambi had better results, but also that both companies made progress in 2012. Bambi's performance improvement arisen as a result of a higher ROOA with positive spread and smaller financial leverage effect. On the other hand, Stark recorded a significant increase in financial leverage in 2012, thanks to which it managed to get closer to Bambi's performance level. A more detailed analysis of Stark's sources of performance in 2012 should indicate if this progress was based on real grounds. Reaching the leader's position for Stark would require further progress in improving RNOA keeping the positive spread. It should be also taken into notice that Bambi will probably keep on with improvement of its own performances as well. 
During the whole period, Bambi had higher gross profit margins and higher operating profit margins, even with higher participation of all cost categories (Picture 2). Therefore, the possibilities for improvement of operating profit margin for Stark lie in the increase of gross profit margin, i.e. in increase of sales and decrease of direct material costs (keeping the same quality of inputs), as well as the purchased value of goods sold. Both companies could achieve additional increase in operating profit margin in the following period, through minimization of salaries and other operating expenses.

Table 1. Profitability analysis for the purpose of financial benchmarking (in 000 RSD)

\begin{tabular}{|c|c|c|c|c|c|}
\hline \multirow{2}{*}{ No } & \multirow{2}{*}{ ITEM } & \multicolumn{2}{|c|}{ BAMBI } & \multicolumn{2}{|c|}{ STARK } \\
\hline & & 2012 & 2011 & 2012 & 2011 \\
\hline 1 & Gross operating profit / Revenue & 61.61 & 57.70 & 46.86 & 42.77 \\
\hline 2 & Administrative expenses / Revenue & 1.52 & 0.83 & 0.56 & 0.58 \\
\hline 3 & Advertising / Revenue & 8.43 & 7.86 & 6.82 & 6.13 \\
\hline 4 & Salaries / Revenue & 15.25 & 16.65 & 13.71 & 15.06 \\
\hline 5 & Other operating expenses / Revenue & 17.26 & 18.16 & 13.77 & 12.43 \\
\hline 6 & Operating profit margin (1-2-3-4) & 19.14 & 14.20 & 11.99 & 8.57 \\
\hline 7 & Income & $8,226,378$ & $7,829,170$ & $8,164,999$ & $6,960,230$ \\
\hline 8 & Average net operating assets (NOA) & $4,776,182$ & $4,763,483$ & $4,645,382$ & $4,869,111$ \\
\hline 9 & Average current operating assets & $3,756,691$ & $3,623,672$ & $4,702,616$ & $3,700,469$ \\
\hline 10 & Average long-term operating assets & $2,603,467$ & $2,668,377$ & $2,763,999$ & $2,790,059$ \\
\hline 11 & Average operating liabilities & $1,583,976$ & $1,528,566$ & $2,821,233$ & $1,621,417$ \\
\hline 12 & Operating current assets TO ratio inverse & 0.46 & 0.46 & 0.58 & 0.53 \\
\hline 13 & Operating long-term assets TO ratio inverse & 0.32 & 0.34 & 0.34 & 0.40 \\
\hline 14 & Operating liabilities TO ratio inverse & 0.19 & 0.20 & 0.35 & 0.23 \\
\hline 15 & Turnover ratio (ATO) (7/8) & 1.72 & 1.64 & 1.76 & 1.43 \\
\hline 16 & Return on net operating assets (RNOA) $(6 * 15)$ & 32.97 & 23.34 & 21.07 & 12.25 \\
\hline 17 & Average net financial obligations (NFO) & 850,644 & $1,274,951$ & $2,022,112$ & 511,961 \\
\hline 18 & Average stockholders' equity (SE) & $3,925,538$ & $3,488,532$ & $2,623,270$ & $4,357,150$ \\
\hline 19 & Financial leverage (FLEV) (17/18) & 0,22 & $\mathbf{0 , 3 7}$ & 0,77 & $\mathbf{0 , 1 2}$ \\
\hline 20 & Net financial expenses (NFE) & 160,174 & 62,483 & $-149,512$ & 10,883 \\
\hline 21 & Average net financial obligations (NFO) & 850,644 & $1,274,951$ & $2,022,112$ & 511,961 \\
\hline 22 & Net financial expenses rate (NFR) (20/21) & 0,19 & 0,05 & $-0,07$ & 0,02 \\
\hline 23 & SPREAD (RNOA-NFR) (16-22) & 32,78 & 23,29 & 21,14 & 12,23 \\
\hline 24 & ROCE $(16+19 * 23)$ & 40,07 & 31,85 & 37,37 & 13,68 \\
\hline 25 & Operating profit & $1,574,717$ & $1,111,731$ & 978,722 & 596,363 \\
\hline 26 & Average operating assets & $6,360,158$ & $6,292,049$ & $7,466,615$ & $6,490,528$ \\
\hline 27 & ROOA $(25 / 26)$ & 24,76 & 17,67 & 13,11 & 9,19 \\
\hline 28 & Average operating liabilities & $1,583,976$ & $1,528,566$ & $2,821,233$ & $1,621,417$ \\
\hline 29 & Average net operating assets (NOA) & $4,776,182$ & $4,763,483$ & $4,645,382$ & $4,869,111$ \\
\hline 30 & Operating leverage (OLLEV) (28/29) & 0.33 & 0.32 & 0.61 & 0.33 \\
\hline 31 & ROOA & 24.76 & 17.67 & 13.11 & 9.19 \\
\hline 32 & Short-term borrowing costs rate (STBC) & 0 & 0 & 0 & 0 \\
\hline 33 & SPREAD (ROOA-STBC) & 24.76 & 17.67 & 13.11 & 9.19 \\
\hline 34 & $($ RNOA $($ ROOA+OLLEV*(ROOA-STBC) & 32.97 & 23.34 & 21.07 & 12.25 \\
\hline 35 & $\begin{array}{l}\text { ROCE }=\text { ROOA+OLLEV } * \text { SPREAD }+ \\
\text { FLEV } * \text { SPREAD }\end{array}$ & 40.07 & 31.85 & 37.37 & 13.68 \\
\hline
\end{tabular}

Source: authors' calculation based on financial statements data 
Picture 1. ROCE analysis - first level of the analysis (in RSD)

RNOA

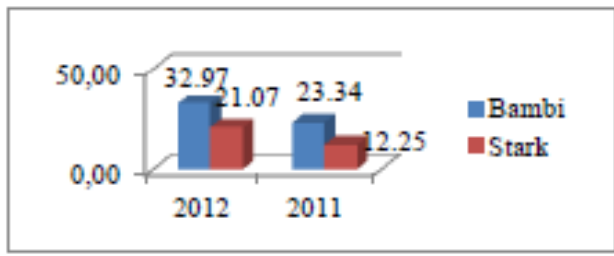

\section{SPREAD}

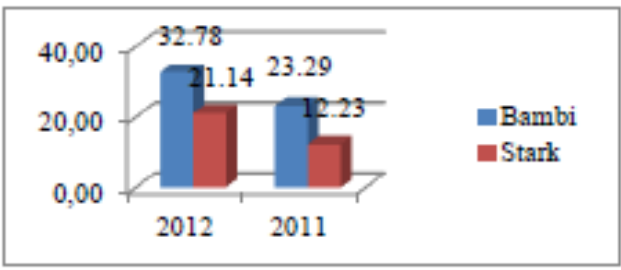

Financial leverage

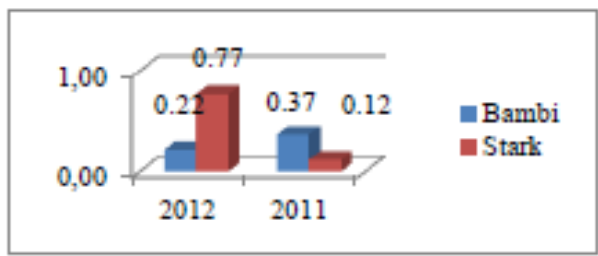

ROCE

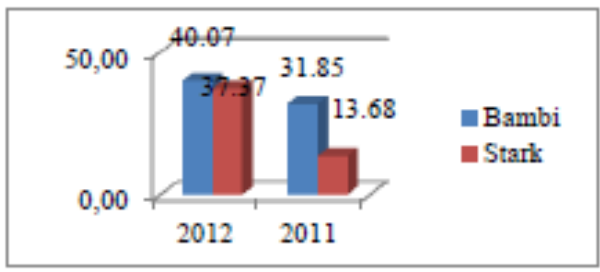

Source: authors' calculation based on financial statements data

For the purpose of the analysis of ROCE value drivers in financial benchmarking of Bambi and Stark, turnover ratios were displayed in their inverse form. This should be taken into account when interpreting results - higher efficiency means lower values of ratios in this case. It is notable that even though Bambi had better results, in 2012 Stark catches up when it comes to efficiency in managing net operating assets. Keeping this trend in the following period would enable Stark to promote its RNOA and increase ROCE. On the other hand, the same goes for Bambi. If Bambi as a leader keeps on with performance improvement, Stark will have to make an additional effort in order to catch up.

Both companies had positive financial leverage effects in the analyzed period. However, different trends were achieved. Bambi had a decrease in financial leverage level in 2012, thanking to a significant decrease in the level of average net financial liabilities in relation to 2011. Still, Bambi managed to achieve growth in ROCE, due to more efficient use of net operating assets (RNOA is at a significantly higher level in 2012 than in previous year).

On the other hand Stark had an exquisite growth in the level of financial leverage. This was due to the simultaneous and significant increase in average net financial liabilities and decrease of average capital. The analysis of Stark's structure of financing sources in 2012 shows atypical changes. Namely, income statement for 2012 shows net profit, but balance sheet shows a loss which led to decrease in capital to $13 \%$ of its value from the previous year, even with the same shareholders equity and significant increase in capital reserves. More detailed research showed that Stark had a status change in 2012, whereas the acquiring company it incorporated two companies which seized to exist (the fact that those were the companies which were the only owners of Stark at that time is not without significance). 
Picture 2. Gross profit margin value driver's analysis - second level of the analysis (in RSD)

Gross profit margin

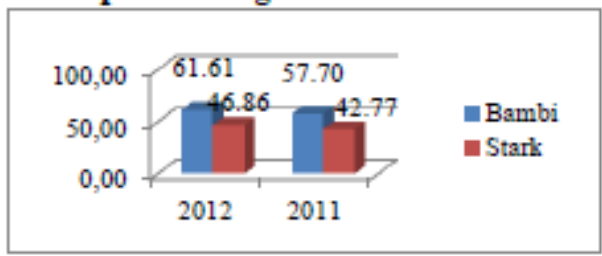

\section{Advertising costs}

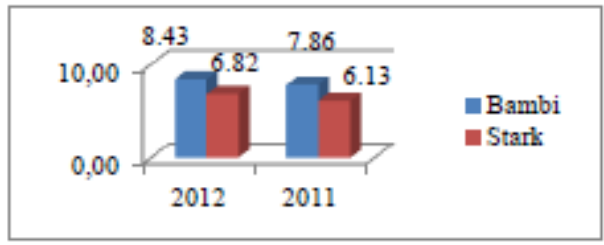

\section{Other operating expenses}

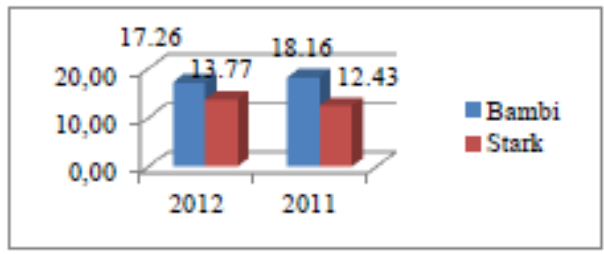

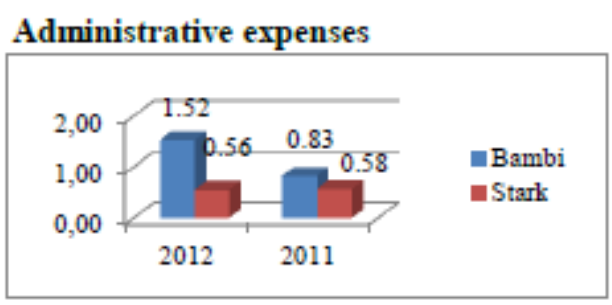

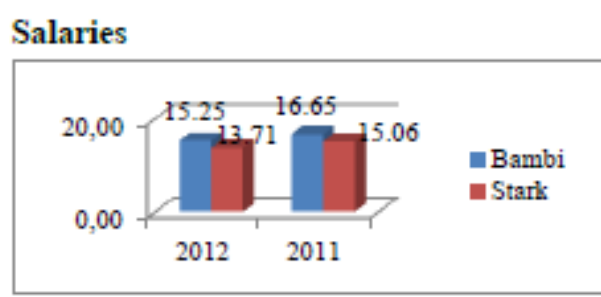

\section{Operating profit margin}

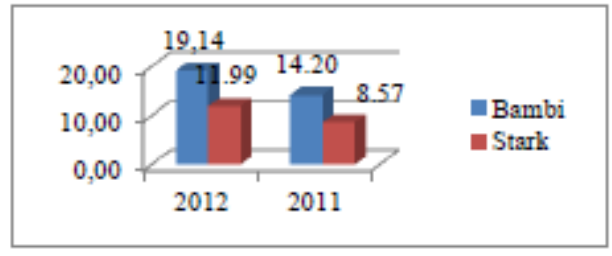

Source: authors' calculation based on financial statements data

Picture 3. Efficiency value driver's analysis - third level of the analysis (in RSD)

Operating current assets TO

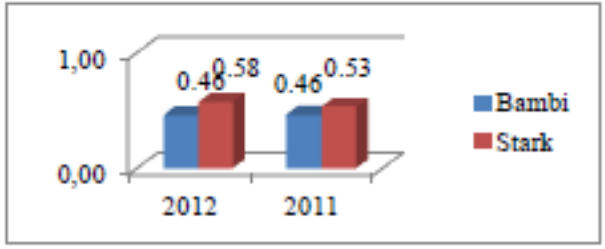

\section{Operating liabilities TO}

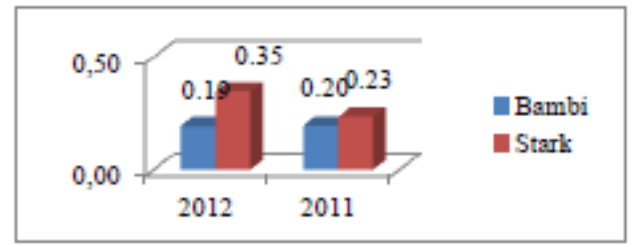

Operating long-term assets TO

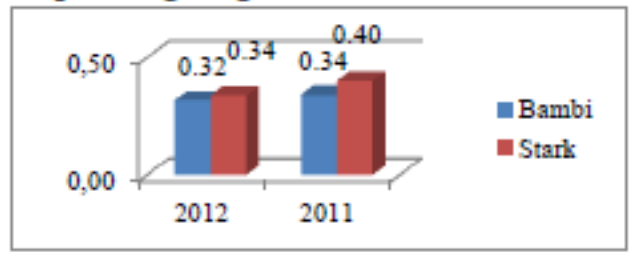

Net operating assets TO

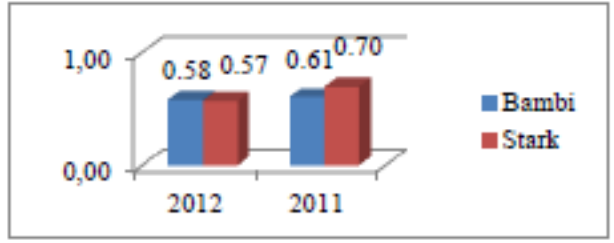

Source: authors' calculation based on financial statements data

Undoubtedly the mentioned transaction had consequences on the financial statements of Stark for 2012, due to which an additional caution is necessary when making conclusions on its performance in the subject year, and especially in projecting its future results. Analy- 
sis in the following years will show whether the significant increase in Stark's ROCE in 2012, thanks to which it got closer to Bambi's performance level, resulted from better management of available assets, or it is just an optical illusion of the financial reporting system.

Bambi and Stark had different trends when it comes to net financial expenses rate (Picture 4). Bambi had a significant increase in net financial expenses in 2012. Together with the decrease of average net financial liabilities, this caused the growth of net financial expenses rate to an almost four times higher level than in 2011. However, thanks to a higher return on net operating assets, Bambi managed to keep a positive spread, and to maintain ROCE on a higher level than RNOA.

On the other side, Stark had higher financial income compared to financial expenses in 2012, which is why the shown net financial expenses rate is negative. Analyzing the available data, we have come to a conclusion that this occurred as a consequence of a significant participation of FX gains in total financial income (probably arisen from the mentioned status change in 2012). At the same time, there was a dramatic increase in the level of average net financial liabilities. Accordingly, it can be concluded that Stark needs to be especially careful in the following period, and to try to keep its 2012 performance level through the improvement of return on net operating assets. Due to the high growth of net financial liabilities, a growth of financial expenses is expected in the future (this would be followed by a higher cash outflows, except if the debt would be converted to capital, which is formally possible for Stark as it had changed its form to limited liability company in 2012).

Picture 4. Net financial expenses analysis (in RSD)

Net financial expenses
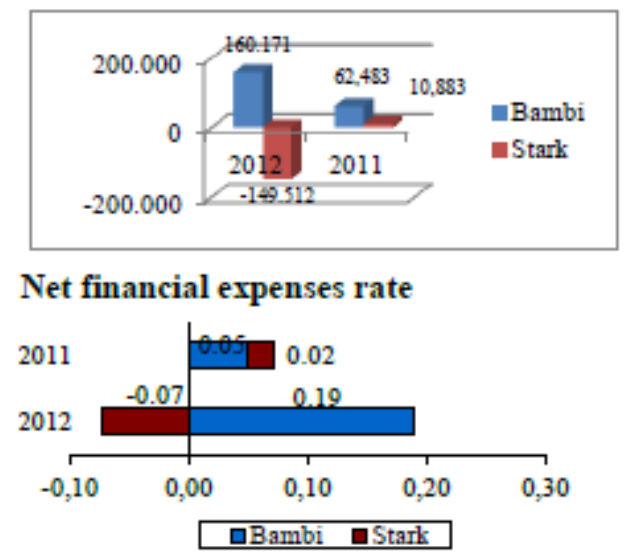

Net financial obligations

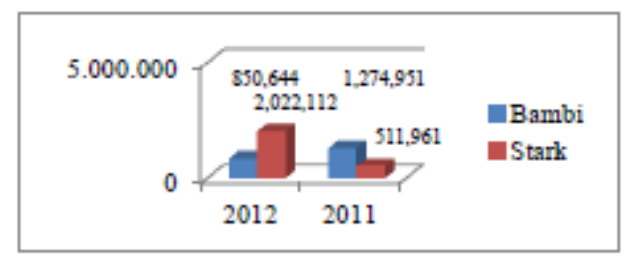

Source: authors' calculation based on financial statements data

Both companies had a significantly higher level of free cash flow in 2012 (Table 2), thanks to higher operating profits but also to disinvestment i.e. decreasing the level of net operating assets. Thereat, Stark's results must be interpreted with caution, due to status change in 2012 (this especially taking into account extremely high level of net financial liabilities in 2012 which Stark needs to repay in the following period). 
Table 2. Cash flow analysis for the purpose of financial benchmarking (in 000 RSD)

\begin{tabular}{|l|r|r|r|r|}
\hline \multirow{2}{*}{ ITEM } & \multicolumn{2}{c|}{ BAMBI } & \multicolumn{2}{c|}{ STARK } \\
\cline { 2 - 5 } & \multicolumn{1}{|c|}{$\mathbf{2 0 1 2}$} & \multicolumn{1}{c|}{$\mathbf{2 0 1 1}$} & \multicolumn{1}{c|}{$\mathbf{2 0 1 2}$} & \multicolumn{1}{c|}{$\mathbf{2 0 1 1}$} \\
\hline Operating profit & $1,393,007$ & $1,057,560$ & $1,135,374$ & 556,287 \\
\hline Change in net operating assets (NOA) & $-67,335$ & 92,733 & $-720,358$ & 272,900 \\
\hline Free cash flow (FCF) & $\mathbf{1 , 4 6 0 , 3 4 2}$ & $\mathbf{9 6 4 , 8 2 7}$ & $\mathbf{1 , 8 5 5 , 7 3 2}$ & $\mathbf{2 8 3 , 3 8 7}$ \\
\hline
\end{tabular}

Source: authors' calculation based on financial statements data

The final step in the performance analysis is the market indicators analysis. In normal circumstances, it is expected that continuous liquidity, strong financial structure, efficient asset and capital management and increasing profitability are translated into appropriate high and growing market values (Malinić et al., 2013). However, one of the basic assumptions for that to happen is the existence and functioning of the financial market i.e. the existence of enough stock transactions in order to form a relevant market price. It is necessary to point out that this assumption was not completely fulfilled when it comes to Stark, due to which calculated market indicators need to be interpreted with caution.

Namely, the volume of transactions with Stark's stocks was negligible from the very beginning of their appearance on the stock market, and in 2013 the company seized to exist as a public company. On this occasion, the majority owner performed a compulsory purchase of the remained stocks at 1,420 RSD per share, which can be considered as the indicator of the lower limit of Stark's shares value at that time. On the other hand, market price of Bambi's shares had an increasing trend in 2013 and 2014, and it reached a record of 38,500 RSD in January 2014. This represents an additional confirmation of abovementioned stance on market valuation of companies with good performances, even in the case of undeveloped financial market of the Republic of Serbia.

Analyzing market indicators of Bambi and Stark (Table 3), as a final aspect of their performance analysis for financial benchmarking purposes, we have come to several conclusions. Namely, it is obvious that financial market highly valuates Bambi, regardless of the fact that it made a shift in its dividend policy and that total shareholder's return decreased. A significant portion of earnings was retained in the company and it is expected to contribute to its future growth and the increase in its share value, accordingly (which had shown in the years that followed). When creating dividend policy, companies necessarily consider the dividend preferences of the most important shareholders (Zakić et al., 2012). Therefore, Bambi's shareholders favour the policy of low and relatively steady dividends, expecting high capital gains in the future.

On the other hand, Stark's dividend policy in the whole analyzed period consisted of retaining the whole earnings, without payment of dividends. When we have in mind the Stark's ownership structure at the time, where there were few dominant shareholders who finally became the sole owners of Stark thanks to the institution of compulsory share purchase, it is clear that one cannot rely on market information when assessing Stark's performance. Although Stark significantly improved its operating result formally, it is actually yet to use the synergetic effects of the performed status change, above all by searching the possibilities EP 2014 (61) 4 (1037-1051) 
for increasing gross profit margin, through minimizing the costs of material and purchase value of goods sold on one hand, and increasing income, on the other.

Table 3. Market indicator analysis for the purpose of financial benchmarking (in 000 RSD)

\begin{tabular}{|c|c|c|c|c|c|c|}
\hline \multirow{2}{*}{ ITEM } & \multicolumn{3}{|c|}{ BAMBI } & \multicolumn{3}{|c|}{ STARK } \\
\hline & 2012 & 2011 & 2010 & 2012 & 2011 & 2010 \\
\hline Net profit after tax & $1,098,494$ & 897,929 & 556,003 & $1,302,702$ & 574,096 & 526,696 \\
\hline Number of common shares & 360,106 & 382,899 & 382,899 & $3,268,826$ & $3,268,826$ & $3,268,826$ \\
\hline Number of repurchased own shares & 19,947 & 33,764 & 20,178 & 0 & 0 & 0 \\
\hline Weighted average of common shares & 340,159 & 349,135 & 362,721 & $3,268,826$ & $3,268,826$ & $3,268,826$ \\
\hline EPS & 3,229 & 2,572 & 1,533 & 399 & 176 & 161 \\
\hline Nominal share value & 4,100 & 4,100 & 4,100 & 600 & 600 & 600 \\
\hline Market share price & 23,200 & 20,000 & 17,000 & 1,317 & 1,200 & 2,000 \\
\hline $\mathrm{P} / \mathrm{E}$ ratio & 7 & 8 & 11 & 3 & 7 & 12 \\
\hline Bookkeeping share value & 11,792 & 9,203 & 8,826 & 184 & 1,421 & 1,245 \\
\hline Stockholders' equity & $4,246,450$ & $3,523,639$ & $3,379,630$ & 602,855 & $4,643,685$ & $4,070,615$ \\
\hline $\mathrm{P} / \mathrm{B}$ ratio & 2 & 2 & 2 & 7 & 1 & 2 \\
\hline DPS & 669 & 524 & 1,260 & 0 & 0 & 0 \\
\hline DPR & $20.70 \%$ & $20.37 \%$ & $82.20 \%$ & $0.00 \%$ & $0.00 \%$ & $0.00 \%$ \\
\hline Capital gain & 3,200 & 3,000 & 8,750 & 117 & -800 & 600 \\
\hline TSR & 3,869 & 3,524 & 10,010 & 117 & -800 & 600 \\
\hline
\end{tabular}

Source: authors' calculation

Picture 5. Market indicators analysis (in RSD)

\section{EPS}

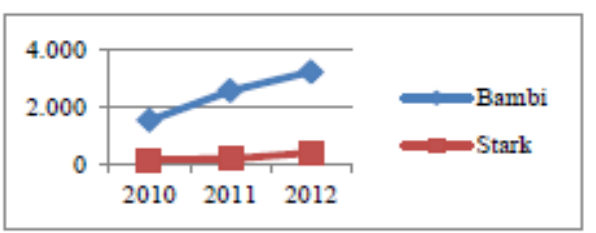

\section{$\mathbf{P} /$ E ratio}

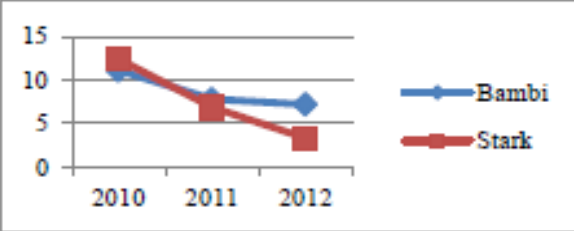

TSR

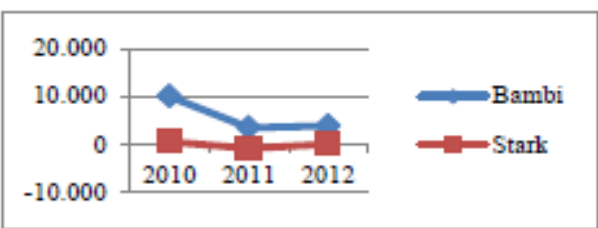

$\mathrm{P} / \mathrm{B}$ ratio
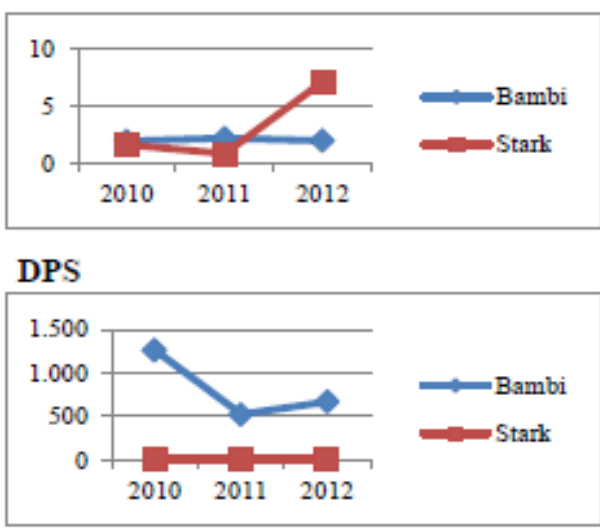

\section{DPR}

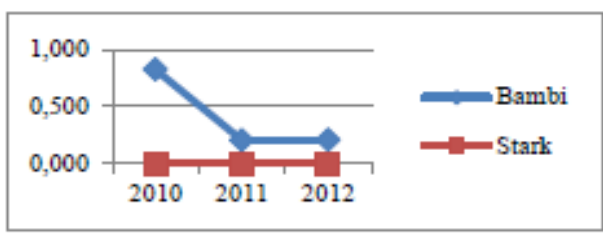

Source: authors' calculation 
Nevertheless, the performance analysis is only the initial step in the process offinancial benchmarking. It enables a company to locate its current position in relation to the benchmarking partner and to set realistic improvement goals relative to effective performance (APO, 2005). It is well known that managing a modern company can no longer be based only on the information generated in within a company (Milićević, 2006). Once a company knows what other organizations are achieving, it can use that information to set appropriate targets (Stapenhurst, 2009). Benchmarking against best identified practices, if suitably adopted and adapted, can generate a company considerable profit of performance within a very short time (Maire et al., 2005). The problem is to define and identify "the best". It is usually the undisputed leader in the process that is critical to a business success - regardless of the sector or the location (Codling, 1995).

It should also be pointed out that performance measurement is never a onetime act, and that it needs to be performed continuously in several successive periods. Namely, the benchmarking process actually begins with identification of performance gap (and gap in value drivers). However, focusing on performance measures gives little information about how to improve and close the gap to partner. If learning, motivation and improvement are to be the result of benchmarking, it requires that the causes for the performance gap are the focus of attention (Andersen, Pettersen, 1995). In the following phases of the benchmarking process, after taking on the appropriate activities for performance improvement, measurement is necessary to be repeated continuously, in order to identify the result of the activities taken, but also to follow the position of the benchmarked leader. Managing performances in order to reach (and outrun) the leader (or other benchmarking partner), one should always be aware of the fact that the leader itself will also work on improving his own performance in the same period. In other words, it is expected that targeted performance level goes higher and higher from period to period. The benchmarking process is continuous because of the high rate of change in the business environment due to which benchmarks are continually redefined (Zairi, Leonard, 1994). It is a journey toward true improvement and excellence (PERI, 1999).

The results of our analysis clearly indicate that Stark must act on multiple fronts in order to reach the performance level of the benchmarked leader. Above all, it is necessary to react on minimizing the expenses of direct material and goods, in order to increase gross profit, with the same or increasing income. Considering current trends in the economy and agriculture, it is very difficult to expect the decrease of production costs (Todorović, Filipović, 2010). Stark could, for example, invest in improvement of production process in a technological aspect, which would enable the production of the same final product but with the use of cheaper material or decreased other production expenses. Even a smaller promotion in the production organization can result in significant savings of production expenses, and accordingly improve the company's performance. That said Stark would especially benefit from benchmarking with Bambi on the level of certain products or production lines, where they are direct competitors. However, this type of benchmarking would require intense cooperation between benchmarking partners and exchange of business information, which is not likely to happen when it comes to these companies. Stark could possibly benchmark with leaders from other food industries or international leaders from the same industry, to acquire new knowledge on 
the possibilities for technological or organizational improvement of the production process. Unfortunately, recent research into the use of benchmarking in the food supply chain among distributors, manufacturers and retailers has shown that there is relatively little evidence of benchmarking, despite its popularity in other commercial sectors (Jack, 2012).

On the other hand, it would be useful for Stark to consider the possibility of increasing sales through additional expenses for advertising and product branding which could result in higher volume of sales in the following period, or possible increase in sale prices of its products. Also, Stark should look for indices on those customer needs which are not adequately satisfied by the leader through its own product range, using market research tools, and then adjust its products accordingly.

Possibilities for cost savings lie in the field of other operating expenses, as well. More detailed analysis of available resources and future expected needs can be used for rationalization of the number of employees and cost cutting when it comes to salaries (Đerković, 1999). The same approach can be applied to the group of other operating expenses, as well as the administrative expenses.

One of the challenges for Stark in the following period undoubtedly lies in extremely high short-term liabilities, both operating and financial, which fall due for payment in 2013. That said Stark should especially tend to cash flow management, in order to maintain the liquidity of the company and keep the regular flow of operating activity. Among other things, efforts must be made in turning accumulated receivables into cash.

However we must note that the objectivity of Stark's performance analysis in this case is somewhat limited with the fact that there has been a status change in the recent past, with material effects on the financial statements. When it comes to financial recording, i.e. actually valuating entities involved in a status change, especially when it comes to related entities, experience tells us that such cases require a significant amount of caution.

For those very reasons, Stark approaching Bambi's performances in 2012 cannot be considered as a completely reliable conclusion. Better judgment can be made after the analysis of performance in the following years.

\section{Conclusion}

Managing a company and reaching targets has always represented a challenge. In terms of modern businesses and overall crisis, with poor and expensive resources, illiquidity and severe competitors game in extremely turbulent surroundings, business decision making actually turns to everyday battle for survival. In order to successfully overcome the obstacles they encounter on a daily basis, managers must have a whole arsenal of managerial instruments at their disposal. Embracing well known strategies and wandering through trodden paths is a safe way towards failure.

Turbulent surroundings require continuous vigilance and willingness to take action. The benchmarking process provides just that. Its implementation enables a company to learn using the experience of others, whether they are direct competitors or best practices from other 
industries. This way, a company can be aware of possible moves of a competitor and at the same time prepare a timely response to it, but also to gain useful ideas on how to implement best practices from other industries in order to improve its own performance.

Financial benchmarking is especially useful because it can be performed using publicly available information, with satisfying level of reliability, modest investment and without the actual knowledge and consent of the benchmarking partner. More detailed analysis of performance indicators on the level of value drivers enables a company not just to identify the gap in performances but also to find the possible manners for its reduction i.e. for reaching the level of a leader, and continuous improvement afterwards.

The process of financial benchmarking was elaborated in his paper using the example of two companies doing business in the Republic of Serbia, which are the biggest competitors on the market of biscuits and confectionery products. The leadership of Bambi was confirmed through the multidimensional set of performance indicators, and especially through financial market indicators. On the other hand, preliminary performance analysis, based on return on common equity, had shown that Stark got very close to the leaders performance level in 2012. However, a deeper analysis of Stark's sources of performance casted a shadow of doubt on long-term sustainability in performance of Stark. In other words, for Stark to catch up with leader's performance level in the future, it must seriously deal with possibilities of improvement of its gross profit margin, finding means from increasing sales and cutting costs of material and purchase value of goods sold. We should not forget that Bambi as a leader will at the same time continue to improve its own results, if it manages to keep the previous year trend. Consequently, this continuous performance improvement competing game will potentially result in reaching excellence in the industry as a whole and strengthen its competitiveness on the international market.

Through the elaborated analysis, we have confirmed that financial benchmarking can be used as a tool in different types of organizations, including the agricultural sector, and that it can give very useful indices about the actions which needs to be undertaken in order to improve company's performance in the future. Additionally, we have shown that financial benchmarking performed using only publicly available data is a very cost-effective tool, having in mind that all the necessary information for the analysis can be obtained with minimal effort and free of charge.

\section{Literature}

1. Andersen B., Pettersen, P.G. (1995): Benchmarking Handbook, Chapman and Hall, London, UK.

2. American Productivity \& Quality Center - APQC (1993): The benchmarking management guide, Productivity Press, Cambridge, USA.

3. Asian Productivity Organization - APO (2005): Benchmarking Training Manual, APO Best Practice Network, Japan, Tokyo.

4. Codling, S. (1995): Best Practice Benchmarking: A Management Guide, Gower 
Publishing, Ltd., Aldershot, UK.

5. Đerković, Z. (1999): Organizacija obračuna troškova i učinaka HK "Bambi", Požarevac, Institut za ekonomiku i organizaciju Inek, Beograd.

6. Jack, L. (2012): Benchmarking in Food and Farming: Creating Sustainable Change, Gower Publishing, Ltd., Aldershot, UK.

7. Jašarević, A., Ličina, M. (2013): Franchising as a business concept-chance for many in Serbia, Ekonomika Poljoprivrede, IEP Beograd, vol. 60, br. 3, pp. 523-539.

8. Maire, J.L., Bronet, V., Pillet, M. (2005): A typology of “best practices” for a benchmarking process, Benchmarking: An International Journal, vol. 12, no. 1, pp.45 60, Emerald Group Publishing Limited, Bingley, UK.

9. Malinić, D. (2010): Finansijski benčmarking kao instrument za unapređenje performansi preduzeća, zbornik radova: Uloga finansijske i računovodstvene profesije u prevazilaženju krize u realnom i finansijskom sektoru, Savez računovođa i revizora Republike Srpske, Banja Vrućica, str. 155-179.

10.Malinić, D., Milićević, V., Stevanović, N. (2013): Upravljačko računovodstvo, Ekonomski fakultet, Beograd.

11. Milićević, V. (2006): Koncept konkurentskog računovodstva, Ekonomika preduzeća, Savez ekonomista Srbije, vol. 54, br. 7-8, str. 259-271.

12.Public Entity Risk Institute - PERI (1999): Benchmarking, Best Practices and Performance Measurements for Public Entity Risk Management Guidelines, PERI, available at:www.riskinstitute.org

13.Stapenhurst, T. (2009): The Benchmarking Book, Routledge, London, UK.

14.Škarić, K. (2012): Finansijsko izveštavanje kao instrument zaštite interesa poverilaca društava grupe, Acta Economica (online), no. 16, available at:www.actaeconomica. efbl.org/broj16/e-ActaEconomica-broj16-Skaric.pdf, accessed at 05/02/2014

15. Todorović, S., Filipović, N. (2010): Economic analysis of wheat production on family farms, Journal of Agricultural Sciences, vol. 55, no. 1, pp. 79-87, University of Belgrade, Faculty of Agriculture, Belgrade.

16.Zairi, M., Leonard, P. (1994): Practical Benchmarking: The Complete Guide, Chapman and Hall, London, UK.

17.Zakić, V., Vasiljević, Z., Zarić, V. (2012): Relevance of dividend policy for food industry corporations in Serbia, Ekonomika Poljoprivrede, IEP Beograd, vol. 59, no. 4, pp. 809-822.

Websites:

18.Agencija za privredne registre Republike Srbije, available at: www.apr.gov.rs/, accessed at: 05/02/2014.

19.Beogradska berza, available at: www.belex.rs/, accessed at: 05/02/2014.

20. Centralni registar, depo i kliring hartija od vrednosti, available at: www.crhov.rs/, 
accessed at: 05/02/2014.

21.Bambi ad Požarevac, available at: www.bambi.rs/, accessed at: 05/02/2014.

22.Soko Śtark doo - Beograd, available at: www.stark.rs/, accessed at: 05/02/2014.

23.AC-Broker ad - Beograd, available at: www.ac-broker.rs/akcije/STRK, accessed at: $05 / 02 / 2014$.

\title{
FINANSIJSKI BENČMARKING NA PRIMERU PREDUZEĆA KONDITORSKE INDUSTRIJE
}

\author{
Marina Vasilic ${ }^{2}$
}

\section{Summary}

Kao upravljačka alatka dokazane efikasnosti kada je reč o upravljanju preduzećima u kriznim vremenima, benčmarking koncept još uvek je nedovoljno poznat i primenjen u Republici Srbiji. Cilj ovog rada bio je da rasvetli mogućnosti benčmarking koncepta, i to kroz aspekt finansijskog benčmarkinga, odnosno da izloži jednostavnost njegove upotrebe $i$ koristi koje pruža ovaj koncept, čak i sa aspekta eksternog analitičara. U tom smislu, analizirana su dva najveća konkurenta na tržištu konditorskih proizvoda Republike Srbije, korišćenjem javno dostupnih informacija o njihovom poslovanju. Pomoću višedimenzionog seta merila performansi baziranih na dobitku kao vrhovnom cilju, a uzevši u obzir i vrednost za vlasnike, likvidnost i kapitalizaciju, potvrdili smo tržišni položaj lidera i pronašli pokretače njegovih performansi, odnosno ključne zadatke koje pratilac treba da savlada kako bi unapredio sopstvene rezultate.

Ključne reči: benčmarking, analiza performansi, konditorska industrija, kontinuirano učenje.

2 Marina Vasilić, Master Ekonomista, Asistent, Univerzitet u Beogradu, Poljoprivredni fakultet, Nemanjina 6, 11080 Zemun, Srbija, Telefon: + 381112612664, E-mail: marina.vasilic@agrif.bg.ac.rs 